\title{
Topical observations on centric diatoms (Bacillariophyceae, Centrales) of Lake Como (N. Italy)
}

\author{
Wolfram SCHEFFLER* and Giuseppe MORABITO ${ }^{1)}$ \\ Institute of Freshwater Ecology and Inland Fisheries, Department of Stratified Lakes, Alte Fischerhütte 2, D-16775 Stechlin- \\ Neuglobsow, Germany \\ ${ }^{1)}$ CNR Istituto per lo Studio degli Ecosistemi - Sezione di Idrobiologia ed Ecologia delle Acque Interne, L.go Tonolli 50, 28922 \\ Verbania-Pallanza, Italy \\ *e-mail corresponding author: scheff@igb-berlin.de
}

\begin{abstract}
In 2001 a qualitative analysis of the centric diatoms in Lake Como was made. In this work 15 taxa of the genus of Stephanodiscus, Cyclotella, Melosira, Aulacoseira and Stephanocostis were recorded. Among them the taxa Cyclotella pseudostelligera, C. comensis, C. comensis morphotype minima, C. costei, Stephanodiscus minutulus and Stephanocostis chantaicus were of special interest to us with regard to their morphological and taxonomical features. Morphological variability as well as taxonomical classification is discussed. A short appraisal of the ecological state of the Lake Como is given. Without any further critical considerations all centric taxa of Lake Como recorded from fossil to up-to-date collections are compiled.
\end{abstract}

Key words: Lake Como, phytoplankton, centric diatoms, morphology, taxonomy

\section{INTRODUCTORY NOTES TO LAKE COMO}

Lake Como, located south of the Italian Alps, is the third Italian lake by volume $\left(22.5 \mathrm{~km}^{3}\right)$ and surface (146 $\mathrm{km}^{2}$ ) and is the deepest lake in Italy (maximum depth $410 \mathrm{~m}$, mean depth $202 \mathrm{~m}$ ). The renewal time of the whole lake has been estimated in 12.8 years. The catchment area covers $4522 \mathrm{~km}^{2}$, most of which is formed by calcareous rocks (especially dolomite), with marl and sandstone. Due to its shape (Fig. 1) Lake Como can be subdivided into three sub basins, the western, the eastern and the northern. From the hydrodynamic point of view, Lake Como is oligomictic (Ambrosetti \& Barbanti 1992), with the spring mixing typically involving the upper $150 \mathrm{~m}$ : a complete overturn is a rare event.

Like the other Italian subalpine lakes, Lake Como underwent cultural eutrophication during the sixties (Mosello et al. 1997), but some earlier studies (Monti 1924, 1925, 1929; Baldi et al. 1947) and more recent paleolimnological research (Guilizzoni et al. 1982) testify the original oligotrophic nature of the lake. The worsening of the trophic condition was firstly described by Vollenweider (1965), who reported an hypolimnetic oxygen depletion and a Cyclotella comensis bloom during summer 1961. There were no further investigations until the beginning of the seventies, when some samples collected during a monitoring project (Braga 1972) showed an assemblage dominated by few species, mainly cyanobacteria, at high densities: diatoms were poorly represented in that survey. The phytoplankton characteristics at spring overturn remained basically unchanged until the beginning of the eighties: a survey carried out in 1983-1984 (Mosello et al. 1991) revealed the spring dominance of Stephanodiscus hantzschii, testifying to the high trophic level of the lake.

From 1986, the reduction of the nutrient load following an abatement of phosphorus in detergents, a decrease in industrial effluents and the commissioning of new sewage treatment plants caused the total phosphorus concentration in the Como basin to fall from $71 \mu \mathrm{g}$ $\mathrm{l}^{-1}$ to $40 \mu \mathrm{g} \mathrm{l}^{-1}$ at the spring overturn in 1992. Similar concentrations have been recorded at 1998 and 1999 spring overturn (Buzzi 2002). The most recent investigations on phytoplankton were carried out at the end of the nineties (Bettinetti et al. 2000; Buzzi 2002) and showed a large dominance of Planktothrix rubescens in every season. The most abundant centric diatoms were Stephanodiscus parvus and Stephanodiscus hantzschii, whereas among the pennate diatoms dominated those species commonly found in the other deep subalpine Italian lakes: Fragilaria crotonensis, Asterionella formosa, Aulacoseira islandica morf. helvetica.

\section{MATERIAL AND METHODS}

Pelagic samples were collected from Lake Como starting from the surface up to $25 \mathrm{~m}$ depth at $2.5 \mathrm{~m}$ intervals. The samples were collected on 11.03.2001 at a station outside Como; on 12.03.2001 outside Argegno, Gravedona and Bellagio; on 13.03.2001 outside Lecco; on 23.08. and 10.09.2001 outside Dervio. The samples collected from each site were subsequently pooled into their respective homogeneous single samples differentiated by date and site of collection. The plankton of these homogenized samples were retained on a millipore membrane filter with a maximum pore expanse of $5 \mu \mathrm{m}$ 
and air dried. The diatom taxa were identified (Tab. 1), measured and documented by light microscopy using specimens gentling burning procedure and mounted in Naphrax (Padisàk et al. 1999) and by scanning electron microscopy (Hitachi, S-4500) using air dry specimens.

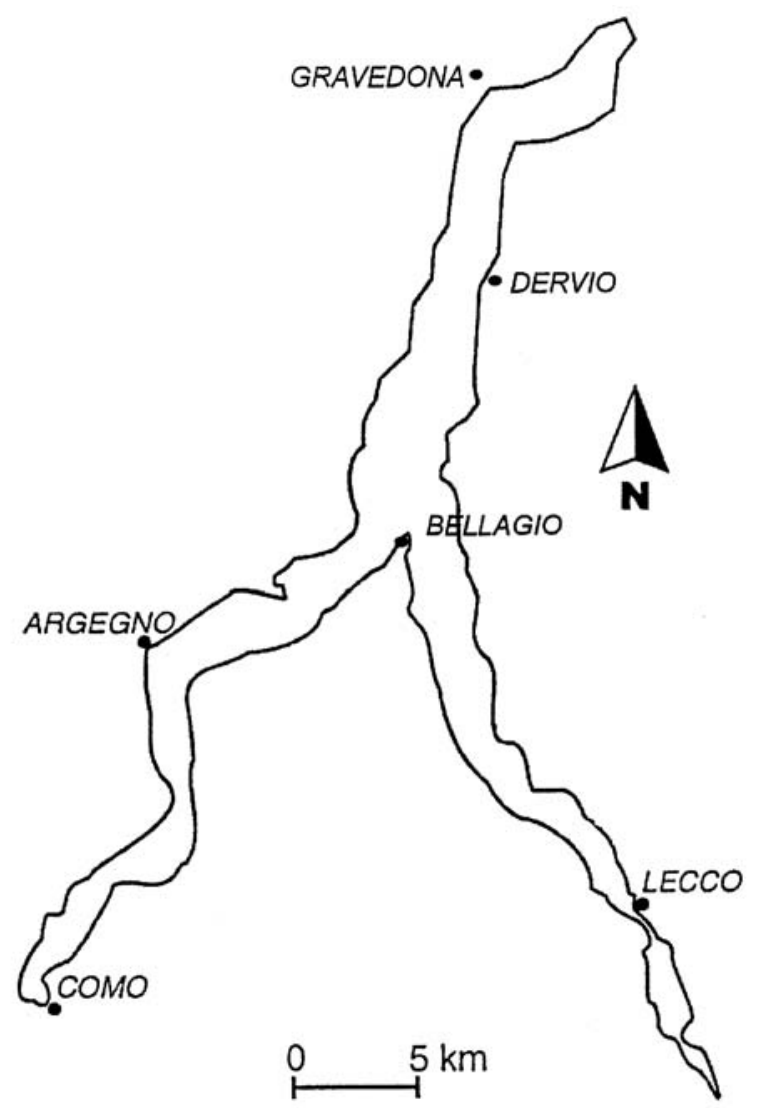

Fig. 1. Lake Como and sampling sites.

Tab. 1. List of the centric diatom taxa observed on 11.-13.03; 23.08 and 10.09.2001 in the phytoplankton community of Lake Como.

Cyclotella comensis Grunow in Van Heurck 1882

Cyclotella costei Druart \& Straub 1988

Cyclotella ocellata Pantocsek 1901

Cyclotella comensis Morphotyp minima Scheffler et al. 2003

Cyclotella radiosa (Grunow) Lemmermann 1900

Cyclotella stelligera Cleve \& Grunow in Van Heurck 1882

Cyclotella pseudostelligera Hustedt 1939

Stephanodiscus alpinus Hustedt 1942

Stephanodiscus neoastraea Håkansson \& Hickel 1986

Stephanodiscus minutulus (Kützing) Cleve \& Möller 1878

Stephanodiscus hantzschii Grunow 1880

Stephanocostis chantaicus Genkal \& Kuzmina 1985

Melosira varians Agardh 1827

Aulacoseira granulata (Ehrenberg) Simonsen 1979

Auloacoseira islandica (O. Müller) Simonsen 1979

\section{RESULTS}

Cyclotella comensis Grunow in Van Heurck 1882

Characteristics $(\mathrm{n}=27)$ :

Diameter $5.3 \mu \mathrm{m}$ (Fig. 5) to $14.8 \mu \mathrm{m}$ (Fig. 3). 14 to 28 striae in $10 \mu \mathrm{m}$ begin at the marginal zone (Figs 2, 10) and end on the central area. They are flat to slight elevated, straight and have a different length (Figs 6, 10). The marginal rows of bigger areoli set in finer areoli (Fig. 10). The central area is tangentially undulated (Figs 4-8). Very rarely the tangential undulation is covered by radial or irregular depressions (Figs 9-11). The central area differs widely with an irregular outlines (Fig. 10). It is strongly formed with differences in size, different quantities, irregularly arranged depressions and protrusions. One fultoportula is situated decentral in the depressed part of the central area (Figs 6, 13, arrows). The marginal fultoportulae are arranged in irregular distances on a depressed costa (Fig. 13) surrounded by two satellite pores (Figs 12-14). One rimoportula is arranged in front or on a costa (Fig. 13, arrow).

Variability

The density of the striae in the radial area is significantly dependent on the diameter of the cells (Fig. 2). The central area is mostly more or less tangentially undulated (Figs 4-8), sometimes radially (Fig. 10) or irregularly corrugated (Figs 9, 11). Depressions and protrusions are fine to coarse (Figs 4, 7, 9), regular colliculate to very irregular in all imaginable transitions (Figs 5, 7, 11), individual to very frequent (Figs 9, 11). The rimoportula is situated before or on a costa (Fig. 13, arrow).

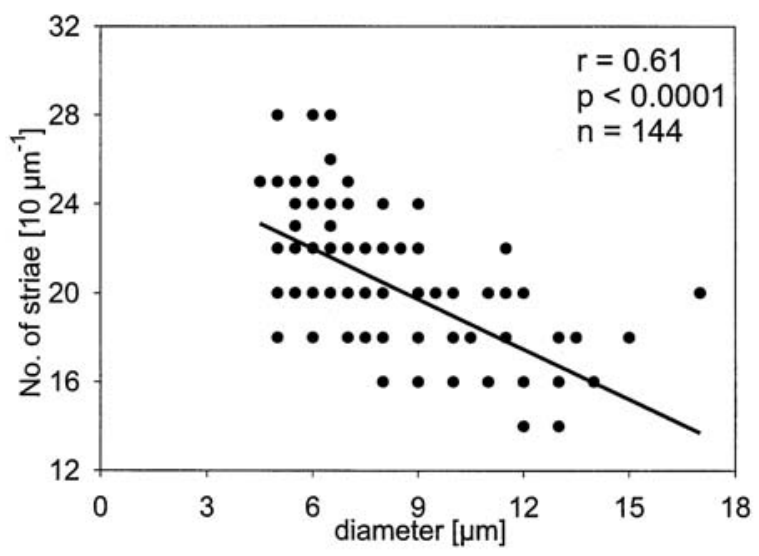

Fig. 2. Cyclotella comensis. Correlation between the diameter of the cells and the number of the striae in $10 \mu \mathrm{m}$.

Discussion

The tangential undulation of the central area seems to be a stable characteristics during the whole vegetative reproduction phase. But it is possible that it can be cov- 
ered by radial dents and curves (Figs 9, 10). The single valves of this species are similar to the structures of $C$. ocellata and can not be clearly classified (Fig. 11). The appearance of radial corrugated cells seems to lead to the fallacy of Håkansson (in Krammer \& Lange-Bertalot 1991) who describes C. comensis exclusive as a radially undulated species. But the same author emphasizes the distinct undulation of the central area (Håkansson 2002, Fig. 349). The tangential undulation of the species however was clearly shown in the drawing of Schmidt et al. (1874-1959), Table 224, Fig. 35. It was proved many times by the material in Grunow-slide 2862. a (Lectotype; Scheffler: unpublished work). We are sure that Cyclotella pseudocomensis (Scheffler 1994) is a synonym of Cyclotella comensis. At the inner surface the valve is smooth. All fultoportulae have two satellite pores. The marginal fultoportlae are arranged at the depressed costae. The only rimoportula is before or on a costa radially, diagonally or sideways arranged (Fig. 13, arrow).

\section{Cyclotella comensis morphotype minima}

Characteristics $(\mathrm{n}=36)$ :

Diameter $2.6 \mu \mathrm{m}$ (Fig. 15) to $6.7 \mu \mathrm{m}$ (Fig. 26). Very slight striae and interstriae begin at the mantle zone and end at or abruptly above the valve faces of the mantle junction. They are flat and straight (Fig. 23). The fine pores of the striae are visible as unregular arrangements, (Figs 21-23). The valve faces are plane to lightly concave (Figs 16, 20). It is regularly structured by slight, sometimes radially orientated depressions and warts. One fultoportula with 0 - 2 satellite pores is situated decentral on the valve face (Figs 25, 26). The marginal fultoportulae are elevated and arranged in irregular distances on a rib and have two satellite pores (Figs 25, 26). One rimoportula is situated radial on a rib (Figs 25, 26, arrows).

\section{Variability}

In their general appearance the cells vary from rollto drum-shaped structure (Figs 15-20). The valve face is plane to slightly concave (Figs 16,18). The areoli end at the valve face mantle junction or go lightly upon it (Figs $22,23)$. The taxon has a small morphological variability.

\section{Discussion}

A taxon of this type is scientifically described as Cyclotella pseudocomensis morphotype minima (Scheffler et al. 2003, in press). It is a morphological individual type (morphotype) of the dimorph species Cyclotella pseudocomensis. It appears in the plankton of North German hardwater lakes in October. It reaches it's quantitative peak in March and is no more detectable from May onwards in the plankton, suggesting that it is a winter-type species. In spring it develops sexual cells.
From the mother cells develop daughter cells of the type Cyclotella pseudocomensis (Scheffler et al. in press. op. cit.). In 2001 this taxon was very frequent observed in the March phytoplankton community of Lake Como. It was not observed in the samples collected in August and September, 2001. We are sure that Cyclotella pseudocomensis (Scheffler 1994) is a synonym of Cyclotella comensis and this taxon is a morphotype of Cyclotella comensis.

A small type was described as Cyclotella gordonensis (Kling \& Håkansson 1988). But the few pictures of that type show cells with areoli arranged in rows. Kling (personal communication in 1998) doubted the legitimacy of the species Cyclotella gordonensis.

\section{Cyclotella costei Druart \& Straub 1988}

Characteristics $(n=40)$ :

Diameter $5.3 \mu \mathrm{m}$ to $8.7 \mu \mathrm{m} .18-20$ striae in $10 \mu \mathrm{m}$ begin at the valve mantle and end at the valve faces. They are plane to slightly elevated and straight (Figs 28, 29). The areoli are arranged in rows. The outer rows of bigger areoli are set in finer areoli in a different frequency (Figs 30-32). The central area is plane with a slightly irregular margin and it takes $50-70 \%$ of the valves diameter. It is smooth without any structures (Figs 27, 28), but it has rarely a few fine depressions (Fig. 29). One decentral valve face of the fultoportula is outside simple round opening (Fig. 28), inside a short tube with one to two satellite pores (Figs 33, 34). Very rarely a fultoportula is missing (Fig. 27). The fultoportulae of the marginal zone are arranged on a depressed rib in irregular distances and have two satellite pores (Figs 33-35). One rimoportula is situated on or before a rib (Figs. 36, 37, arrows). The inside view of the valves is identical to C. comensis (Figs 12-14).

\section{Variability}

There is only a little variation with the size and the outline of the central area. The angle of the rimoportula is changing (Figs 33, 34, arrows). One central fultoportula is exists or is missing (Figs 27, 28). The finer areoli of the striae appear with different frequency (Figs 30-32).

\section{Discussion}

The major morphological characteristics of this taxon is the outline and the structure of the central area. It is plane and rarely shows a slight beginning of a tangential undulation (Fig. 36), without any structures. Corresponding to that the opening of the fultoportula is clearly visible (Fig. 28). Base on the description of our materials, the two possible species could be $C$. distinguenda var. unipunctata (Håkansson \& Carter 1990) and Cyclotella cyclopuncta (Håkansson \& Carter 1990). These Taxa however can neither be clearly identified with the help of the original description nor be separately classified from each other. REM examinations do not exist. 

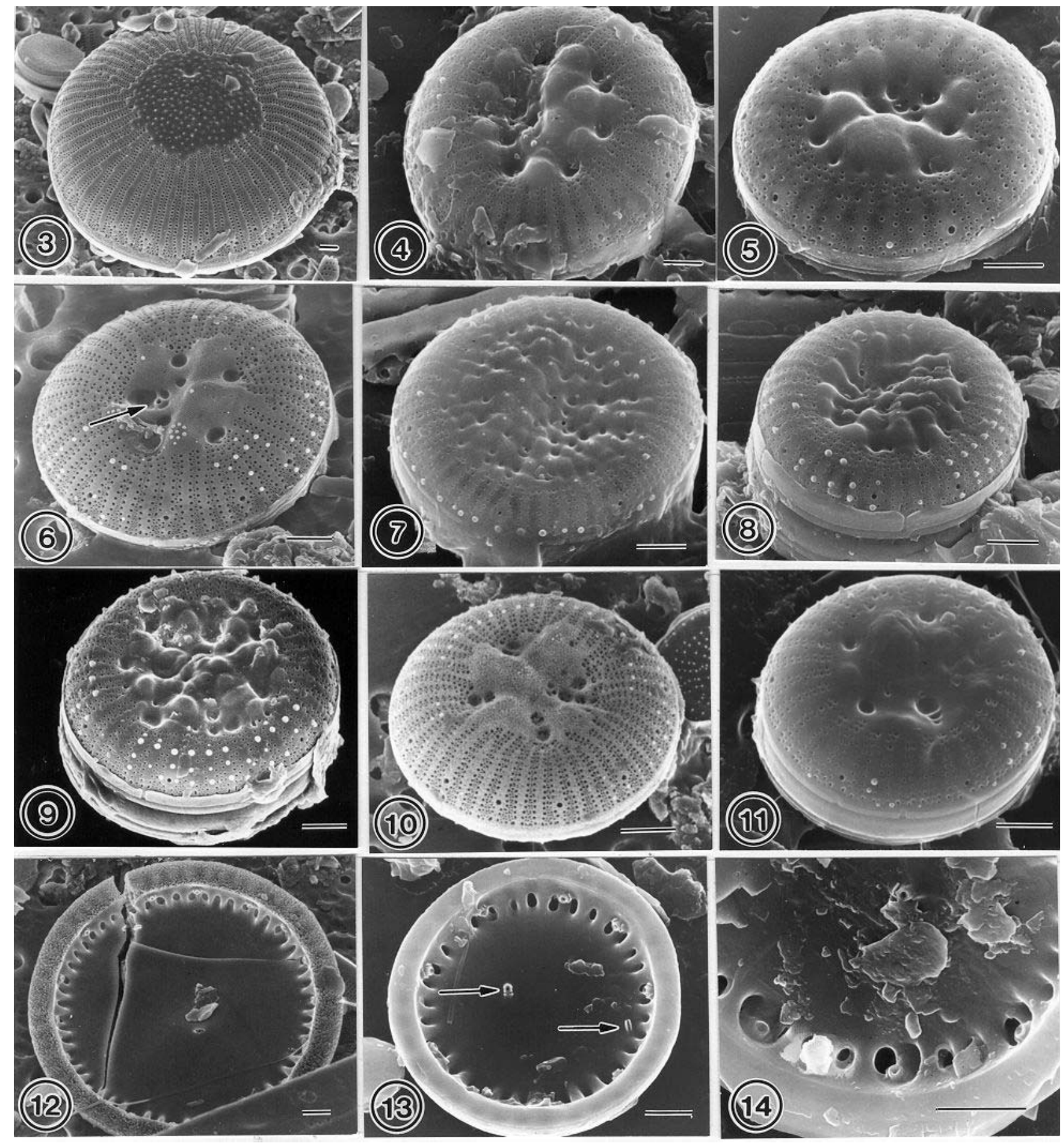

Figs 3-14. REM. Cyclotella comensis. Fig. 3. Initial cell. Figs 4-11. External views of vegetative cells. The structure of the central area varies in a great number. Figs 12-14. Internal views of vegetative cells. The fultoportolae of the marginal zone are inserted on the recessed costae. Scale bars $=1 \mu \mathrm{m}$. 

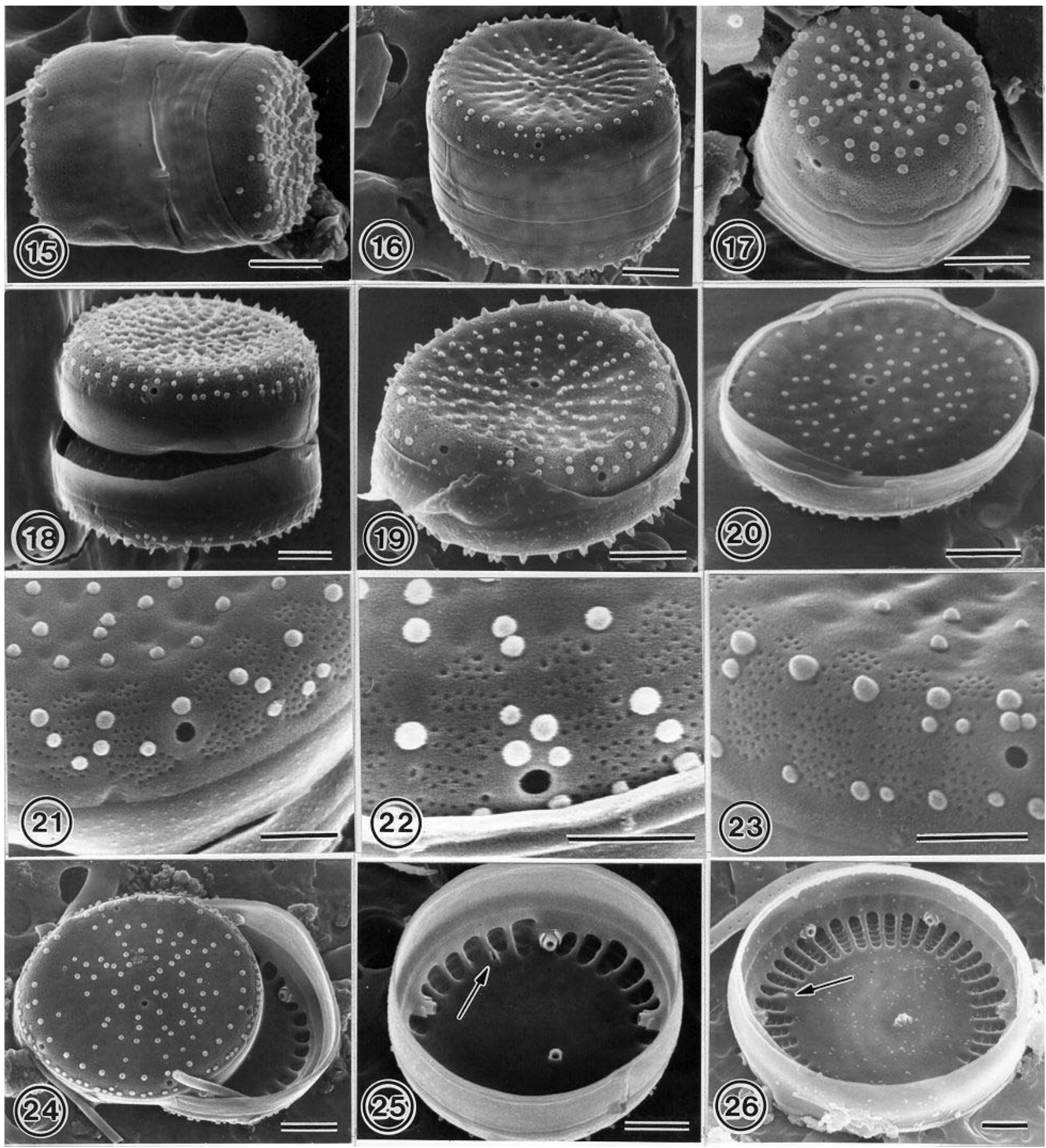

Figs 15-26. REM. Cyclotella comensis morphotype minima. Figs 15-24. External views of vegetative cells. Figs 21-23. The point shaped areoli are not arranged in rows. Figs 25-26. Internal views of vegetative cells. The fultoportulae at the marginal zone are elevated and inserted on the costae. Scale bars: Figs 15-20, 24-26 $=1 \mu \mathrm{m}$. Figs $21-23=0.5 \mu \mathrm{m}$. 

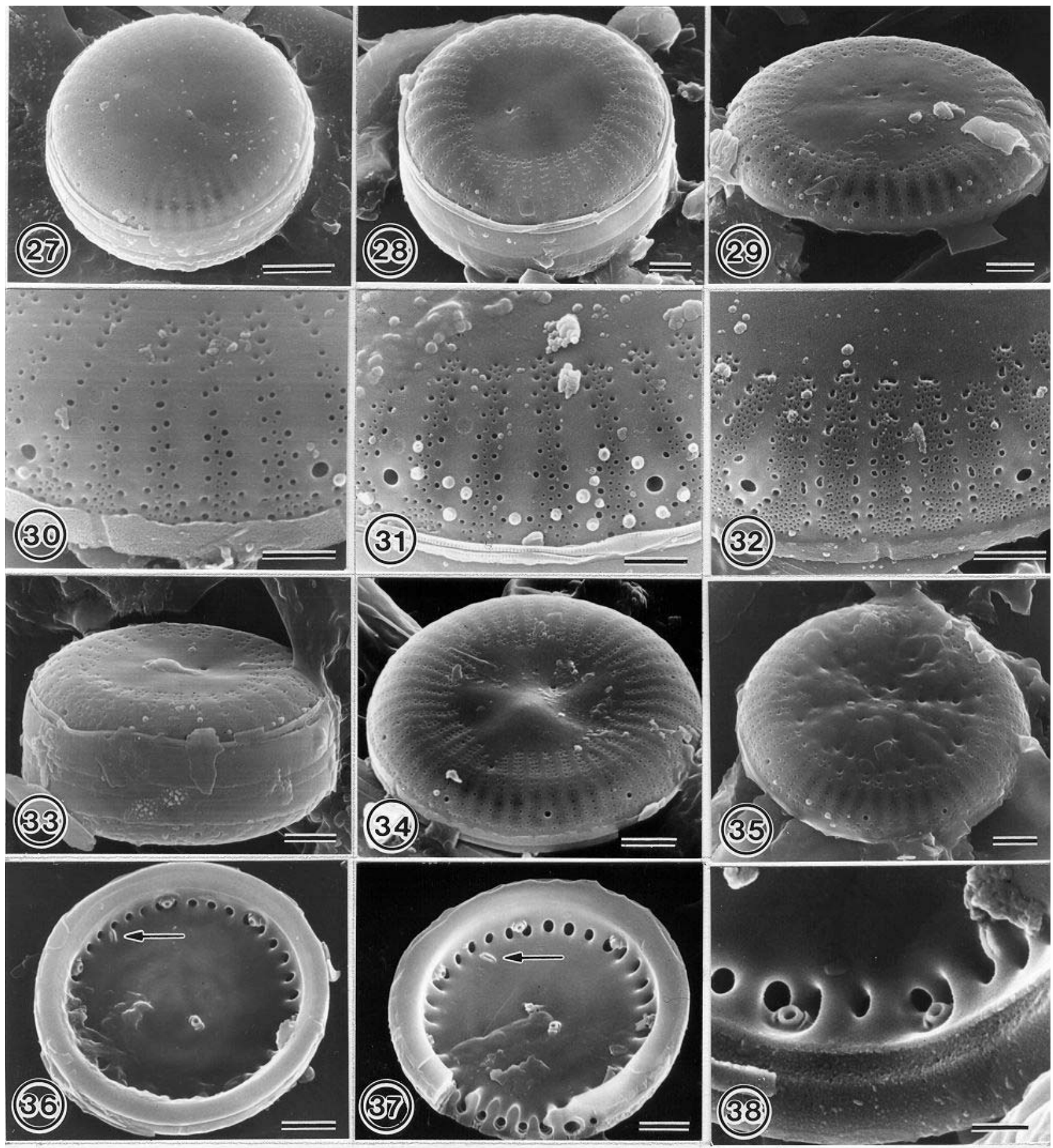

Figs 27-38. REM. Cyclotella costei. Figs 27-35. External views of vegetative cells. Figs 30-32. Between the rows of bigger areoli are finer areoli in irregular order and variable frequency. Figs 33-35. Central area is slight tangential or radial corrugated. At Fig. 35 is the central area slightly structured. Figs 36-38. Internal views of vegetative cells. The fultoportulae at the marginal zone are inserted on the recessed costae (see Figs 12, 14 Cyclotella comensis). Scale bars: Figs 27-29, 33, 34, 36-38 = $1 \mu \mathrm{m}$. Figs 30-32, $38=0.5 \mu \mathrm{m}$. 
Håkansson (2002) considers similarities of both taxa with C. costei (Druart \& Straub 1988). The REMphotographs of this type (Druart \& Straub 1988) are identical to the algae of our material. This is because of the typical depressions of costae as the sitting position of the radial fultoportulae of our algae and hence the typical structure of the central area is described in our material as Cyclotella costei.

What seems remarkable to us is the conspicuous similarity of many of these characteristics to Cyclotella comensis. The inside view of both types is identical. The differences lie in the size, undulation of the valve and the structure of the central area. We have also found a few algae that indicate a morphological transition between the central area of $C$. comensis and $C$. costei (Figs 36-38). These valves are either slightly tangential or slightly radially undulated. Some have a fine but clear structure on the central area. These observations alone are not enough to make any further conclusions. However, the hypothesis should be proved that $C$. costei is probably a morphotype of $C$. comensis. Where $C$. comensis is dominant $C$. costei also appears from time to time in the plankton in oligo- to mesotrophic North German lakes.

\section{Cyclotella pseudostelligera Hustedt 1939}

Characteristics $(\mathrm{n}=72)$

Diameter 2.3 to $5.8 \mu \mathrm{m}$. The shape at the valves of the taxon is nearly always flat (Fig. 39), rarely slight concave (Fig. 45). Areols can be present or missing. Slightly siliceous cells have no areols. Their radially running striae are formed from fine irregularly arranged pores (Figs 41, 44, 50). They run from the mantle (Fig. 44) or from the valve face mantle junction (Fig. 41) to the valve centre. The central area is reached (Fig. 39), nearly reached (Fig. 45) or not reached (Fig. 46). Areols are formed by a rising silicate stratum and have nearly every possible structure and size (Figs 46, 52, 53). Between them the pores can be visible (Figs 56 arrow, 58). The totally flat interstriae (Fig. 41) of slightly siliceous valves change to slight elevated costae with further siliceous deposition (Figs 45-47). A fultoportula is missing from the valve face. Three to seven radial fultoportulae with 2 satellite pores are observed between the costae on the edge to the marginal zone (Figs 44, 45, 50). Inside and outside there are open tubes with different length (Figs 44, 50). Outside, the open tubes can be forked (Fig. 46, arrow). One rimoportula is observed on the costa as a round to bug-narrow opening and set in an elevated bulge (Figs 49, 50, arrows). Their opening at the valve outside it was not visible.

\section{Variability}

This taxon shows a wide variability. Striae are nearly invisible (Figs 40, 43) or very prominent (Fig. 57). Areols can be missing (Figs 40, 41) or be very clearly visible (Figs 57, 58). Their central area is miss- ing (Figs 53, 39) or present in different sizes (Figs 45, $46,57,52$ ). It is flat (Figs 40,52 ) to concentrically undulated (Figs 61, 62).

\section{Discussion}

Many cells of this taxon (Figs 39-44) shows characteristics of Thalassiosira pseudonana (sensu Kiss 1984 Figs 16-23): they are plane, have no separated central area and show no clear areols. The cells crossed with these morphological characteristics divided into the lines between genus Cyclotella and genus of Thalassiosira. Gerloff \& Helmcke (1974) and Kiss (1984) also refer to the similarity of Thalassiosira with Cyclotella. We think that the population of Lake Como belongs to Cyclotella because the cells in our samples have no central fultoportula, as it is typical within the genus Thalassiosira (Krammer \& Lange-Bertalot 1991; Hasle $\&$ Heimdal 1970). None of our algae show an inter-connection of the striae to the comb-shaped alveolae, as it is shown for Thalassiosira pseudonana (Hasle \& Heimdal 1970; Harris et al. 1995). We have then recognised that there is a gentle transition between the cells without central area to the cells with well-developed central area of different sizes (Figs 39, 45, 46). This corresponds to the research findings of Klee \& Houk (1996) and Hübener (1999) on the populations of Cyclotella woltereckii. Cells with a clear beginning to a concentric shaped valve are also found (Figs 60, 61). This broad variability of the important characteristics as well as the consistent similar position of the marginal fultoportulae between the interstriae (Figs 41, 46, 58) give an indication that among the stelligeroid taxa, this taxon belongs to the genus Cyclotella (sensu Houk 1992). Chang \& Steinberg (1989) described some river plankton from Bavaria, Germany with nearly identical characteristics and variabilities to our material. They also placed similar Thalassiosira cells into genus Cyclotella and divided them into four species. The fluent transition of all the characteristics in our materials do not allow, however, a further taxonomical division. Haworth \& Hurley (1986) proved that the characteristics of the stelligeroid taxa can be a result of crossing among themselves and suggested that species Cyclotella glomerata, C. pseudostelligera and $C$. woltereckii be classified as varieties of the species Cyclotella stelligera.

Håkansson in Krammer \& Lange-Bertalot (1991) named this group as Cyclotella stelligera, C. pseudostelligera and $C$. glomerata as proved species. After the research results of the reference material of Cyclotella stelligera (Chang 1991) and our own results of a population of Cyclotella pseudostelligera collected from Kenya (Kotut et al. 1998) there are clear differences between the sizes of the taxa. The diameter of the initial cells beginning from the basic vegetative development stage reaches up to $40 \mu \mathrm{m}$ in Cyclotella stelligera and only up to $15 \mu \mathrm{m}$ in Cyclotella pseudostelligera (Kotut et al. 1998). That is why we call our material from Lake Como Cyclotella pseudostelligera. 

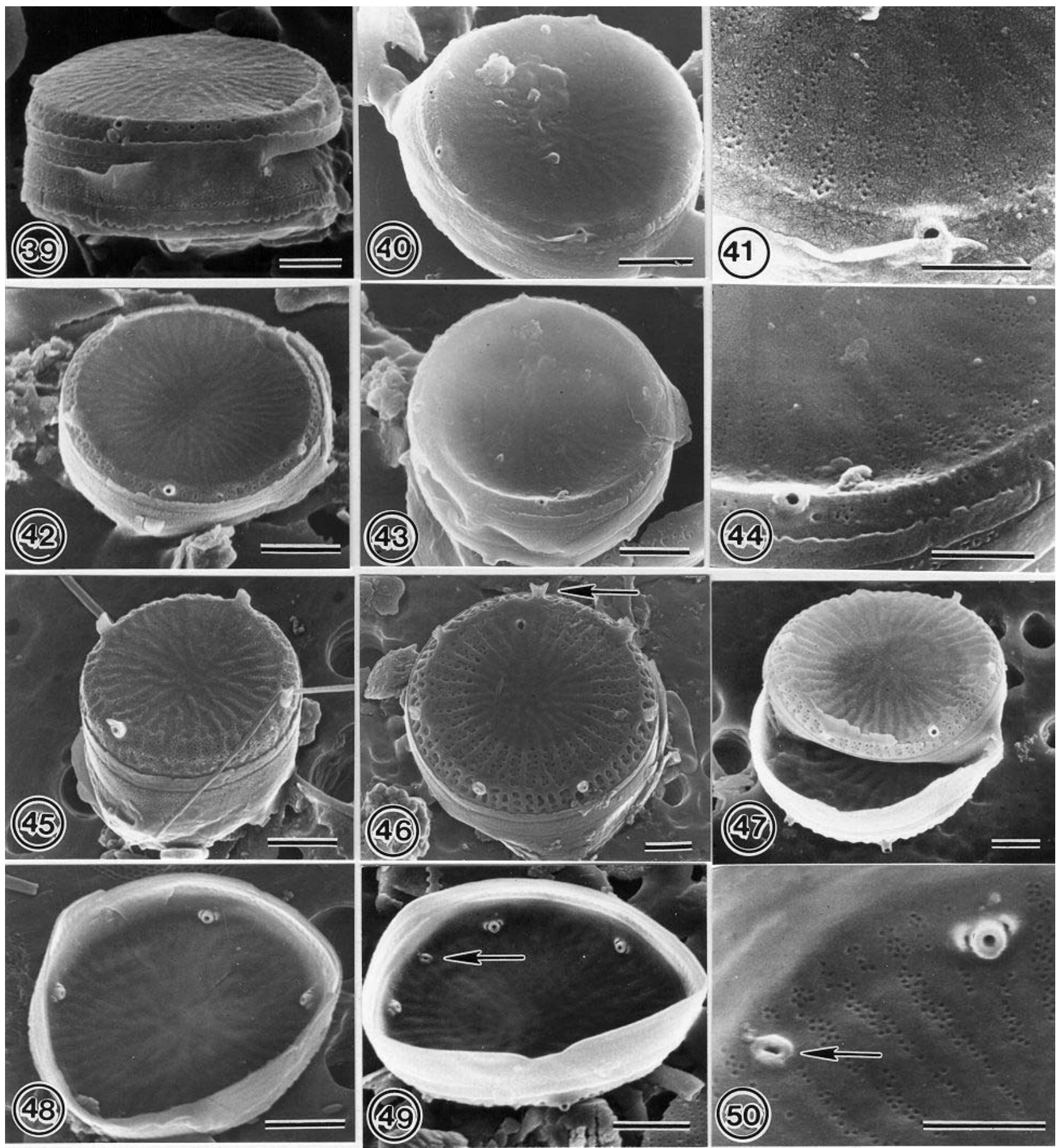

Figs 39-50. REM. Cyclotella pseudostelligera. Figs 39-47. External views of vegetative cells. Figs 41, 44. The striae are formed by finer pores. They are not arranged in rows. Figs 48-50. Internal views of vegetative cells. Fig. 50. The rimoportula is bean-shaped. Scale bars: Figs 39, 40, 42, 43, $45-49=1 \mu \mathrm{m}$. Figs 41, 44, $50=0.5 \mu \mathrm{m}$. 

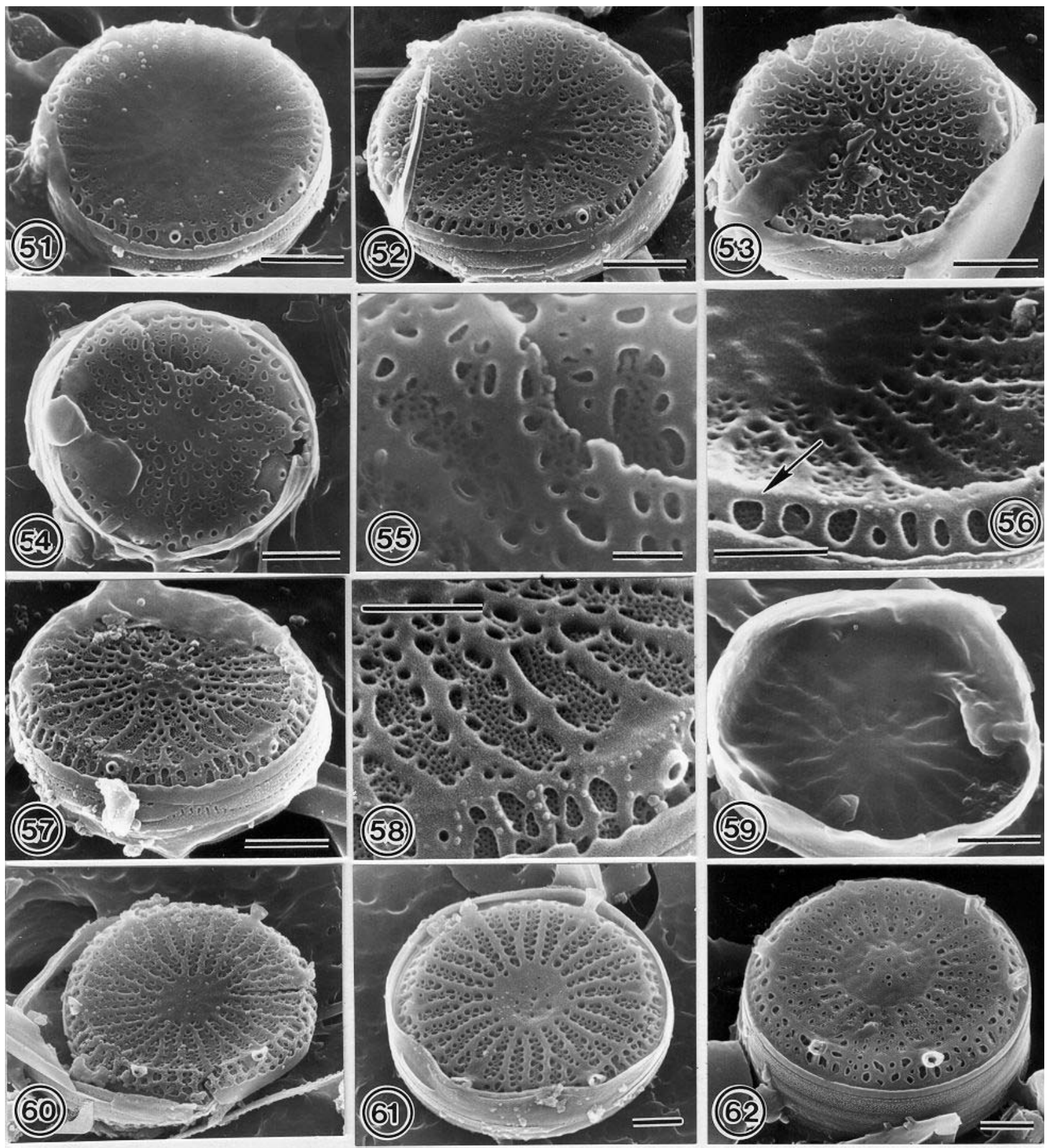

Figs 51-62. REM. Cyclotella pseudostelligera. Figs 51-58, 60-62. External views of vegetative cells. The areoli are variable in form and size. Figs 55, 56 arrow. Between the areoli the pores can be visible. Figs 60-62. The different large central area can be plane or concentrical undulated. Fig. 59. Internal view of vegetative cell. Scale bars: Figs 51-54, 56, 57, $59-62=1 \mu \mathrm{m}$. Figs 55, 56, $58=0.5$ $\mu \mathrm{m}$. 

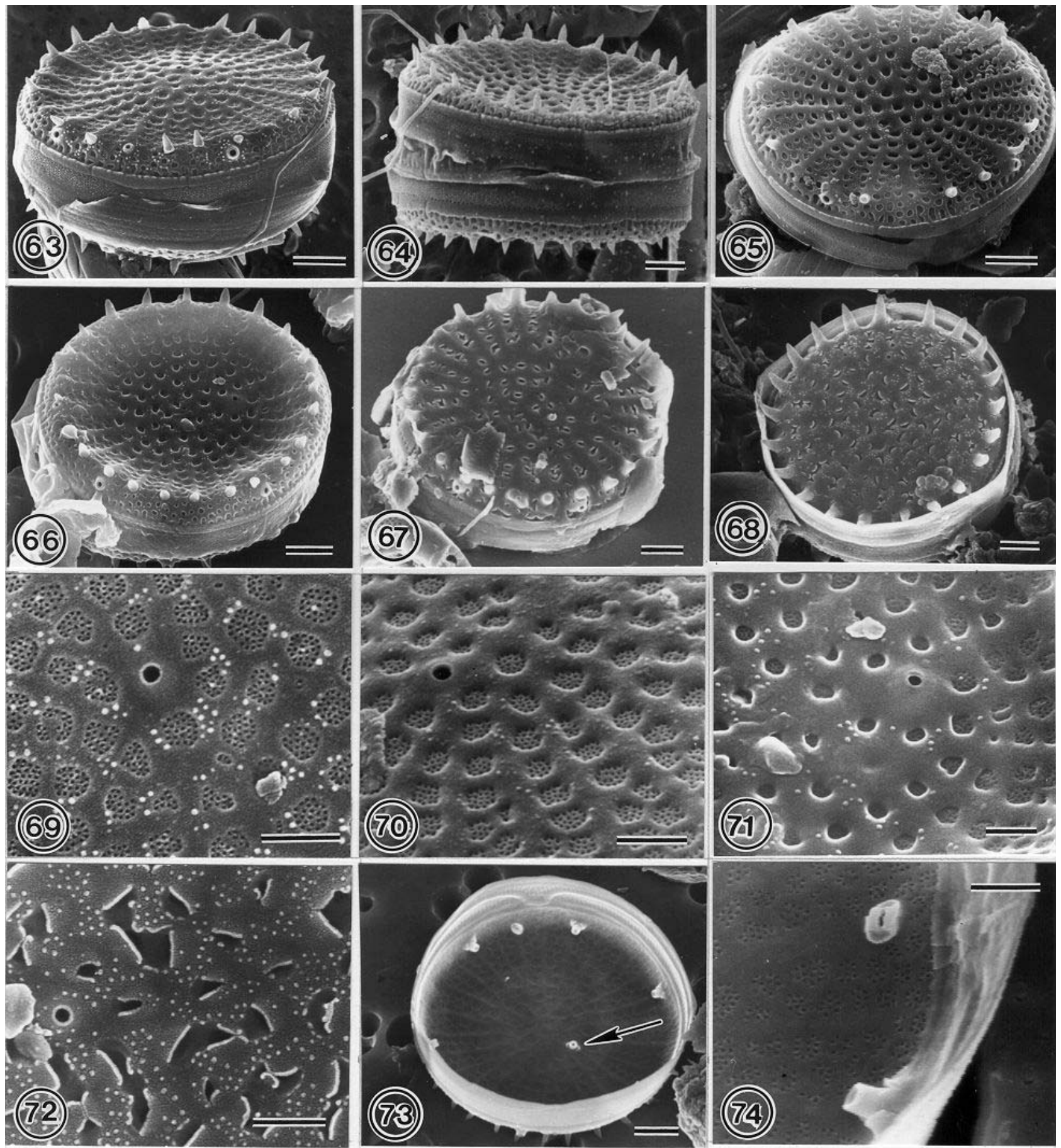

Figs 63-74. REM. Stephanodiscus minutulus. Figs 63-72. External views of vegetative cells. Figs 63-68. The shape of the valve-face is plane or concave or convex undulated. Figs 69-71. Between the areoli the pores of the velum are visible. Figs 73-74. Internal views of vegetative cells. Fig. 74. The rimoportula is beanshaped. Scale bars: Figs 63-68, $73=1 \mu \mathrm{m}$. Figs 69-72, $74=0.5 \mu \mathrm{m}$. 



Figs 75-86. Stephanocostis chantaicus. Figs 75-83. Plankton Lago di Como. Figs 84-86. Plankton Stechlinsee, Germany. Fig. 78. LM. Figs 75-77, 79-86 REM. Figs 75-83. External views of vegetative cells. Figs 84-86. Internal views of vegetative cells. Scale bars: Fig. $78=5 \mu \mathrm{m}$. Figs 75, 79, 81, $84=1 \mu \mathrm{m}$. Figs 76, 77, 80, 82, 83, 85, $86=0.5 \mu \mathrm{m}$. 


\section{Stephanodiscus minutulus (Kützing) Grunow in Cleve \& Möller 1878}

Characteristics $(\mathrm{n}=25)$

Diameter $6.1 \mu \mathrm{m}$ to $7.7 \mu \mathrm{m}$. 12 to 18 striae with sizes of $10 \mu \mathrm{m}$ begin at the valve edge and end at the valve face (Figs 64, 65). They do not, however, reach the centre of the valve. The areols are in quite different form and are not mostly arranged in rows (Figs 63, 66$68)$. On the outline, they are irregularly rounded, polygonal or slit-shaped (Figs 69-72). Based on their size and form, the cribrum may be visible (Figs 69, 70) or invisible (Fig. 72) beneath them. Every costa ends with a spine at the valve face or mantle junction (Fig. 66). The valve face is flat (Figs 65, 67, 68), slightly concave (Fig. 64) or slight concentrically undulated (Fig. 63). One valve face of the fultoportula ends outside as a round opening (Figs 69-71) and inside as a short tube with two satellite pores (Figs 73, arrow). There are fultoportulae at the marginal area in irregular distances with three satellite pores. The initial angle of the beanshaped rimoportula is changing.

\section{Variability}

The valve faces change from flat over slightly concave to slightly concentrically corrugated. The shape of the areols is extremely variable. With the exception of circular or rounded areols, one can find every possible shape with irregular outlines (Figs 66-72).

\section{Discussion}

Stephanodiscus minutulus can be easily confused with Stephanodiscus parvus Stoermer \& Håkansson 1984. The only differentiating characteristics are the shape and position of the valve facing the fultoportula. It should be concentrically corrugated in S. minutulus and plane in S. parvus (Håkansson in Krammer \& Lange-Bertalot 1991). The position of the valve face fultoportula should be heterotopic in S. minutulus and slightly eccentric in S. parvus (Håkansson 2002). A few material we have collected from Lake Como show both forms of the valves at the same time (Figs 65, 69). Like Kobayashi, Kobayashi \& Idei (1985) we also hold that $S$. parvus is a synonym of $S$. minutulus.

\section{Stephanocostis chantaicus Genkal \& Kuzmina 1985}

Characteristics $(\mathrm{n}=6)$ :

Diameter $5.3 \mu \mathrm{m}$ to $5.6 \mu \mathrm{m}$. The strongly elevated costae are strikingly characteristics for both the genus and the species. They begin at the valve face junction and unite in the centre of the valve. They are bound and partly branched (Figs 75-83). Pores and areols are not visible from the outside view. They are structurally covered by long narrow or round narrow silicious structures (Figs 76, 80, 82, 83). One decentral fultoportula on the valve face and a few fultoportulae in the marginal zone are short tubes (Figs 76, 77). In our material of Lake Como the valves of the inside view are not presented in the figures. But they are found to be similar to the inner structures we recorded in the algae collected from Lake Stechlin (Figs 84-86). The striking ribs are slightly visible. Pores of the cribrum are united and slightly elevated. A bean-shaped rimoportula is set on a rib.

\section{Variability}

The siliceous structure found between the ribs is remarkably variable. At every valve it is differently structured (Figs 76, 77, 80, 82, 83) and so can have neither an ecological significance nor taxonomic importance.

\section{Discussion}

The monotypical genus Stephanocostis is rare all over the world. Up to year 2000, the genus was found at 17 locations or research sites circumpolar in the northern hemisphere (Scheffler \& Padisàk 2000) including Lake Como (Wunsam 1993). The species seems to prefer deep, dimictic oligo- to meso-trophic lakes. All the research sites are known to be slightly alkaline. They have a slight to middle $\mathrm{Ca}^{++}$concentration with conductivity between 50 to $406 \mu \mathrm{S} \mathrm{cm}^{-1}$ (Scheffler \& Padisàk 2000). Lake Como is up to now the most southern research site where this species is found. The range of distribution of the genus must be proved critically. Some ultra-structural characteristics of this species are similar to genus Cyclostephanos (Scheffler \& Padisàk 2000).

\section{CONCLUSIONS}

The phytoplankton of Lake Como is characterized by a high diverse flora of centric diatoms. All the centric taxa recorded in Lake Como from fossil to upto-date collections are listed in Appendix. The morphological variability of the species Cyclotella comensis covers the characteristics of Cyclotella pseudocomensis and Cyclotella pseudocomensis morphotype minima. Therefore, both taxa are declared as synonyms of $C$. comensis. The morphological variability of $C$. pseudostelligera, C. costei and Stephanocostis chantaicus is documented and wider as expected. The morphological variability of Stephanodiscus minutulus is high and corresponds with the literature data.

\section{ACKNOWLEDGMENTS}

The authors are deeply grateful to F. Buzzi (ARPA, Lecco) and Adelheid Scheffler for collecting some of the samples analysed during this study. We are also grateful to Rolf Klee for his various kind of help during preparation of this manuscript. We wish to thank Birke Scheffler for correcting in English. 


\section{REFERENCES}

Ambrosetti, W. \& L. Barbanti. 1992. Physical Limnology: an historical review. Mem. Ist. ital. Idrobiol., 50: 37-60.

Ambrosetti, W., Barbanti, L., Mosello R. \& A. Pugnetti. 1992. Limnological studies on the deep southern Alpine lakes Maggiore, Lugano, Como, Iseo and Garda. Mem. Ist. ital. Idrobiol., 50: 117-146.

Baldi, E., L. Pirocchi \& V. Tonolli, 1947. Relazione preliminare sulle ricerche idrobiologiche e limnologiche nelle acque del Lago di Como. Istituto Italiano di Idrobiologia: $35 \mathrm{pp}$.

Barbanti, L., Mosello, R., Pugnetti, A. \& D. Ruggiu. 1986. La limnologia del Lario: dai primi studi alle ricerche attuali. Atti del Convegno: Risanamento del Lago di Como: la ricerca scientifica. Como, 25 Ottobre 1986: 16-43.

Bettinetti, A., Morabito, G. \& A. Provini. 2000. Phytoplankton assemblage structure and dynamics as indicator of the recent trophic and biological evolution of the western basin of Lake Como (N. Italy). Hydrobiologia, 435: 177-190.

Braga, L. 1972. Quadro limnologico recente (1970-1971) del Lago di Como: aspetti fisici e chimici, popolamento fitoplanctonico e produzione primaria. Tesi di laurea in Scienze Biologiche, Università di Milano: 97 pp.

Buzzi, F. 2002. Phytoplankton assemblages in two sub-basins of Lake Como. J. Limnol., 61(1): 117-128.

Castracane, F. 1883. Studio su le Diatomee del lago di Como. Atti dell'Accademia Pontificia de'Nuovi Lincei. Sessione VIa del 21. Maggio 1882: 119-129.

Chang, T.P. 1991. Elektronenmikroskopische Untersuchungen an dem Typusmaterial der zentrischen Kieselalge Cyclotella stelligera Cleve et Grunow. Diatom Research, 6: 1-14.

Chang, T.P. \& C. Steinberg. 1989. Identifizierung von nanoplanktischen Kieselalgen (Centrales, Bacillariophyceae) in der Rott und im Rott-Stausee (Bayern, Bundesrepublik Deutschland). Arch. Protistenkd., 137: 111-129.

Druart, J.C. \& F. Straub. 1988. Description de nouvelles Cyclotelles (Bacillariophyceae) de milieux alcalins et eutrophes: Cyclotella costei nov. sp. et Cyclotella wuethrichiana nov. sp. Schweizerische Zeitschrift für Hydrologie, 50: 182-188.

Gerloff, J. \& J.-G. Helmcke. 1974. In: Helmcke, J.-G., W. Krieger and J. Gerloff (Eds), Diatomeenschalen im elektronenmikroskopischen Bild. Volume VIII, Lubrecht \& Cramer Ltd: pls 715-824.

Guilizzoni, P., G. Bonomi, G. Galanti \& D. Ruggiu. 1982. Basic trophic status and recent development of some Italian lakes as revealed by plant pigments and other chemical components in sediment cores. Mem. Ist. ital. Idrobiol., 40: 79-88.

Håkansson, H. 1990. Cyclotella tripartita nov. spec. and the relationship to similar taxa. Ouvrage dédié á H. Germain. Koeltz. 75-82.

Håkansson, H. \& J.R. Carter. 1990. An Interpretation of HUSTEDT's Terms "Schattenlinie" "Perlenreihe" and "Höcker" Using Specimens of the Cyclotella radiosacomplex, $C$. distinguenda HUST. and C. cyclopuncta nov. spec. Jour. Iowa Acad. Sci., 97: 153-156.

Håkansson, H. 2002. A compilation and evaluation of species in the general Stephanodiscus, Cyclostephanos and Cyclotella with a new genus in the family Stephanodiscaceae. Diatom Research, 17:1-139.

Harris, A.S.D., L.K. Medlin, \& K.J. Jones. 1995. Thalassiosira species (Bacillariophyceae) from a Scottish sea-loch. Eur. J. Phycol., 30: 117-131.

Hasle, G.R. \& B.R. Heimdal. 1970. Some species of the centric diatom genus Thalassiosira studied in the ligth and electron microscopes. Nova Hedwigia Beih., 31: 559-581.

Haworth, E. Y. \& M. A. Hurley. 1984. Comparison of the Stelligeroid Taxa of the Centric Diatom Genus Cyclotella.
In: Ricard, M. (Ed.), Proc. 8th Int. Diatom Symp. Paris, Aug. 27-Sept. 1. Koeltz Sci. Books: 43-58.

Houk, V. 1992. Cyclotella asterocostata Lin, Xie et Cai (Bacillariophyceae) - a little known stelligeroid Cyclotella species from China. Algological Studies, 67: 33-43.

Hübener, T. 1999. Morphology and ultrastructure of a population of Cyclotella woltereckii Hustedt (Bacillariophyceae) in Northern Germany. Nova Hedwigia, 68: 469-476.

Kiss, K.T. 1984. Occurrence of Thalassiosira pseudonana Hasle and Heimdal (Bacillariophyceae) in some rivers of Hungary. Acta Botanica Hungarica, 30: 277-287.

Klee, R. \& V. Houk. 1996. Morphology and Ultrastructure of Cyclotella woltereckii Hustedt (Bacillariophyceae). Arch. Protistenkd., 147: 19-27.

Kling, H. \& H. Håkansson. 1988. A ligth and electron microscope study of Cyclotella species from central and northern Canadian lakes. Diatom Research, 3: 55-82.

Kobayasi, H., H. Kobayashi \& M. Idei. 1985. Fine structure and taxonomy of the small and tiny Stephanodiscus (Bacillariophyceae) species in Japan. 3. Co-occurrence of Stephanodiscus minutulus (Kütz.) Round and S. parvus Stoerm. and Håk. Jap. J. Phycol., 33: 293-300.

Kotut, K., L. Krienitz, W. Scheffler, M. Engels \& I. Grigorszky. 1998. Some interesting cyanoprocaryotes and algae from Turkwel Gorge Reservoir, Kenya. Arch. Hydrobiol. Suppl. 126: Algological Studies, 91: 37-55.

Krammer, K. \& H. Lange-Bertalot. 1991. Bacillariophyceae 3. Teil: Centrales, Fragilariaceae, Eunotiaceae. In: H. Ettl, J. Gerloff, H. Heynig \& D. Mollenhauer (Eds), Süsswasserflora von Mitteleuropa, Vol. 2/3. G. Fischer, Stuttgart \& New York: $876 \mathrm{pp}$.

Marchetto, A. \& R. Bettinetti. 1995. Reconstruction of the phosphorus history of two deep subalpine Italian lakes from sedimentary diatoms, compared with long-term chemical measurements. Mem. Ist. ital. Idrobiol., 53: 27-38.

Monti, R. 1924. La limnologia del Lario in relazione al ripopolamento delle acque e della pesca. Tip. Luzzati, Roma: $502 \mathrm{pp}$.

Monti, R. 1925. La "fioritura" delle acque sul Lario. Regio Istituto Lombardo di Science e Lettere. Estratto dai Rendiconti - Vol. LVIII - Fasc. XVI-XX: 3-12.

Monti, R. 1929. Limnologia comparata dei laghi insubrici. Verh. int. Ver. Limnol., 4: 462-497.

Mosello, R., D. Ruggiu, A. Pugnetti \& M. Moretti. 1991. Observed trends in the trophic conditions and possible recovery of the deep subalpine Lake Como (N. Italy). Mem. Ist. ital. Idrobiol., 49: 79-97.

Mosello, R., A. Calderoni \& R. de Bernardi. 1997. Le indagini sull'evoluzione dei laghi profondi sudalpini svolte dal C.N.R. Istituto Italiano di Idrobiologia. In: R. Mosello \& G. Giussani (Eds), Evoluzione recente della qualità delle acque dei laghi profondi sudalpini. Documenta Ist. ital. Idrobiol., 61: 19-32.

Padisák, J., L. Krienitz \& W. Scheffler. 1999. Phytoplankton. In: W.v. Tümpling \& G. Friedrich (Eds), Biologische Gewässeruntersuchung. Bd. 2. Gustav Fischer, Jena, Stuttgart, Lübeck, Ulm: 39-40.

Ruggiu, D. 1983. Caratteristiche e comportamento del fitoplancton nei laghi profondi subalpini. In: Ambrosetti, W., Barbanti, L., Mosello, R., Rolla, A. \& D. Ruggiu (Eds), Mescolamento, caratteristiche chimiche, fitoplancton $e$ situazione trofica nei laghi profondi subalpini. CNR - P. F. Promozione della qualitá dell'ambiente. AQ 2/20: 105-146.

Scheffler, W. 1994. Cyclotella pseudocomensis nov. sp. (Bacillariophyceae) aus norddeutschen Seen. Diatom Research, 9: 355-369.

Scheffler, W., A. Nicklisch \& D. Hepperle. (2003). Dimorphism in Cyclotella pseudocomensis (Heterokontophyta, Bacillariophyceae) as revealed by morphological, ecological and molecular methods. Arch. Hydrobiol.: in press. 
Scheffler, W. \& J. Padisák. 2000. Stephanodiscus chantaicus (Bacillariophyceae): morphology and population dynamics of a rare centric diatom growing in winter under ice in the oligotrophic Lake Stechlin, Germany. Algological Studies, 98: 49-69

Schmidt, A., M. Schmidt, F. Fricke, H. Heiden, O. Müller \& F. Hustedt. 1874-1959. 1900. Atlas zur Diatomaceenkunde. Heft 1-120, Tafeln 1-460. Aschersleben - Leipzig.

Straub, F. 1987. A propos de Cyclotella comensis Grunow (Bacillariophyceae). Cahier de biologie marine, 28. 319-322.

Van Heurck, H. 1880-1885. Synopsis des Diatomées de Belgique. Text, Atlas. Anvers.: $235 \mathrm{pp}$
Vollenweider, R. 1965. Materiali ed idee per una idrochimica delle acque insubriche. Mem. Ist. ital. Idrobiol., 19. 213286.

Wunsam, S. 1993. Diatomeen (Bacillariophyceae) als Bioindikatoren in Alpenseen. Transferfunktionen zwischen Diatomeen und Umweltvariablen (ALPTROPH). Dissertation zur Erlangung des Doktorgrades an der Formal- und Naturwissenschaftlichen Fakultät der Universität Wien: $147 \mathrm{pp}$.

Wunsam, S., R. Schmidt \& R. Klee. 1995. Cyclotella-taxa (Bacillariophyceae) in lakes of the Alpine Region and their relationship to environmental variables. Aquatic Sciences, 57: 360-386.

Received: October 2002

Accepted: January 2003

\section{APPENDIX}

Centric diatoms of the plankton of Lake Como published in scientific journals to date, listed in alphabetical order. Under the names of each species, the references of the authors who mentioned that particular diatom are listed in chronological order of publication. The references we cited cover the period from 1882 up to 2000 . All diatom names are given exactly as they were originally published.

\begin{tabular}{|c|c|}
\hline Species & Authors \\
\hline Aulacoseira islandica $\mathrm{O}$. Müll. & Bettinetti et al. 2000 \\
\hline Aulacoseira subarctica (O. Müll.) Haworth & Bettinetti et al. 2000 \\
\hline Cyclotella antiqua $\mathrm{Sm}$. & Castracane 1883 \\
\hline Cyclotella comensis (comta var.?) Grun. & Van Heurck 1882 \\
\hline Cyclotella comta & Ruggiu 1983 \\
\hline Cyclotella dendrochera $\mathrm{E}$. & Castracane 1883 \\
\hline Cyclotella distinguenda & Marchetto \& Bettinetti 1995 \\
\hline Cyclotella distinguenda unipunctata & Marchetto \& Bettinetti 1995 \\
\hline Cyclotella cf. gordonensis & Wunsam 1993 \\
\hline Cyclotella operculata $\mathrm{Hz}$. & Castracane 1883 \\
\hline Cyclotella planctonica & Marchetto \& Bettinetti 1995 \\
\hline Cyclotella pseudostelligera & Marchetto \& Bettinetti 1995 \\
\hline Cyclotella punctata $\mathrm{Sm}$. var.Cesatii Cstr. & Castracane 1883 \\
\hline Cyclotella sp. & Bettinetti et al. 2000 \\
\hline Cyclotella sp. 1 & Marchetto \& Bettinetti 1995 \\
\hline Cyclotella (Discoplea) Sinensis E. & Castracane 1883 \\
\hline Cyclotella stelligera & Marchetto \& Bettinetti 1995 \\
\hline Cyclotella cf. stelligeroides & Wunsam 1993; Marchetto \& Bettinetti 1995 \\
\hline Cyclostephanos dubius & Marchetto \& Bettinetti 1995 \\
\hline Melosira arenaria Moore & Castracane 1883 \\
\hline Melosira distans $\mathrm{Kz}$. & Castracane 1883 \\
\hline Stephanodiscus minutulus & Marchetto \& Bettinetti 1995 \\
\hline Stephanodiscus minutulus (Kuetz.) Cleve \& Möller & Bettinetti et al. 2000, Wunsam 1993 \\
\hline Stephanodiscus parvus & Marchetto \& Bettinetti 1995 \\
\hline
\end{tabular}

